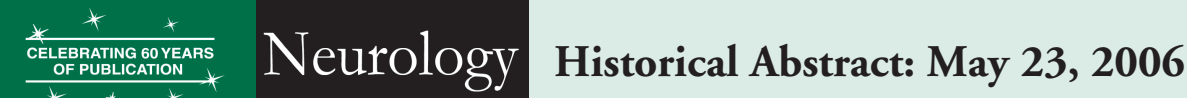

\section{REVISED DIAGNOSTIC CRITERIA FOR NEUROMYELITIS OPTICA}

D. M. Wingerchuk, V. A. Lennon, S. J. Pittock, C. F. Lucchinetti, and B. G. Weinshenker

Neurology 2006;66:1485-1489

Background: The authors previously proposed diagnostic criteria for neuromyelitis optica (NMO) that facilitate its distinction from prototypic multiple sclerosis (MS). However, some patients with otherwise typical NMO have additional symptoms not attributable to optic nerve or spinal cord inflammation or have MS-like brain MRI lesions. Furthermore, some patients are misclassified as NMO by the authors' earlier proposed criteria despite having a subsequent course indistinguishable from prototypic MS. A serum autoantibody marker, NMO-IgG, is highly specific for NMO. The authors propose revised NMO diagnostic criteria that incorporate NMO-IgG status. Methods: Using final clinical diagnosis (NMO or MS) as the reference standard, the authors calculated sensitivity and specificity for each criterion and various combinations using a sample of 96 patients with NMO and 33 with MS. The authors used likelihood ratios and logistic regression analysis to develop the most practical and informative diagnostic model. Results: Fourteen patients with NMO (14.6\%) had extra-optic-spinal CNS symptoms. NMO-IgG seropositivity was $76 \%$ sensitive and $94 \%$ specific for NMO. The best diagnostic combination was $99 \%$ sensitive and $90 \%$ specific for NMO and consisted of at least two of three elements: longitudinally extensive cord lesion, onset brain MRI nondiagnostic for MS, or NMO-IgG seropositivity. Conclusions: The authors propose revised diagnostic criteria for definite neuromyelitis optica (NMO) that require optic neuritis, myelitis, and at least two of three supportive criteria: MRI evidence of a contiguous spinal cord lesion 3 or more segments in length, onset brain MRI nondiagnostic for multiple sclerosis, or NMO-IgG seropositivity. CNS involvement beyond the optic nerves and spinal cord is compatible with NMO.

Free Access to this article at www.neurology.org/content/66/10/1485

Comment from Richard M. Ransohoff, MD, Associate Editor: This report crystallized the recognition that NMO and MS were pathogenetically distinct, by incorporating a new serum biomarker NMO-lgG in the diagnostic criteria. 


\section{Neurology}

\section{Revised diagnostic criteria for neuromyelitis optica}

D. M. Wingerchuk, V. A. Lennon, S. J. Pittock, et al.

Neurology 2011;76;2009

DOI 10.1212/01.wnl.0000398908.30918.e1

This information is current as of June 6, 2011

\section{Updated Information \&}

Services

Permissions \& Licensing

Reprints including high resolution figures, can be found at: http://n.neurology.org/content/76/23/2009.full

Information about reproducing this article in parts (figures,tables) or in its entirety can be found online at:

http://www.neurology.org/about/about_the_journal\#permissions

Information about ordering reprints can be found online:

http://n.neurology.org/subscribers/advertise

Neurology ${ }^{\circledR}$ is the official journal of the American Academy of Neurology. Published continuously since 1951, it is now a weekly with 48 issues per year. Copyright Copyright $@ 2011$ by AAN Enterprises, Inc.. All rights reserved. Print ISSN: 0028-3878. Online ISSN: 1526-632X.

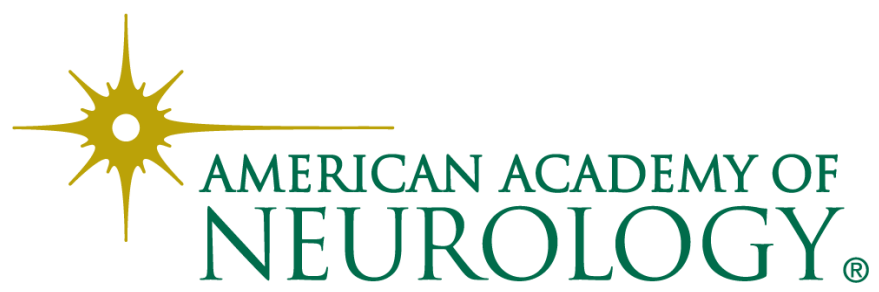

